\title{
Sistem Informasi Penjualan Berbasis Desktop pada Rumah Laundry Kiloan
}

\author{
Gilbert Frederick Yacob Daulima1), Nuraini Purwandari²) \\ Sistem Informasi, Fakultas Industri Kreatif Institut Teknologi dan Bisnis Kalbis \\ Jalan Pulomas Selatan Kav. 22, Jakarta 13210 \\ Email: gilbertfr21@gmail.com \\ Email: nuraini.purwandari@kalbis.ac.id
}

\begin{abstract}
Rumah Laundry Kiloan is a business that offers laundry services. This business still uses a conventional transaction system. So that the system used in Rumah Laundry Kiloan still has shortcomings and risks. The system used has the risk of losing customer notes, damage and loss of ledgers. This study aims to help business processes that are running at Rumah Laundry Kiloan, so that they can overcome problems and reduce the risks of Rumah Laundry Kiloan by building a desktop-based sales information system that includes saving transactions, adding transactions, adding customer data, store customer data, and all fields included in the transaction. The system development method used is a prototype development method. The results of this study are an information system that can be used by Rumah Laundry Kiloan that have been tested with black box testing.
\end{abstract}

Keywords: desktop, information system, laundry, prototype, sales

\begin{abstract}
Abstrak: Rumah Laundry Kiloan adalah bisnis yang menawarkan jasa pencucian pakaian. Bisnis ini masih menggunakan sistem transaksi yang konvensional. Sehingga sistem yang digunakan pada Rumah Laundry Kiloan masih memiliki kekurangan dan memiliki resiko. Sistem yang digunakan memiliki resiko kehilangan nota pelanggan, kerusakan dan kehilangan nya buku besar. Penelitian ini bertujuan untuk membantu proses bisnis yang sedang berjalan pada Rumah Laundry Kiloan, sehingga dapat mengatasi masalah dan mengurangi resiko-resiko yang dimiliki Rumah Laundry Kiloan dengan cara membangun sebuah sistem informasi penjualan yang berbasis desktop yang meliputi penympanan transaksi, menambahkan transaksi, menambah data pelanggan, menyimpan data pelanggan, dan segala bidang yang termasuk dalam transaksi. Metode pengembangan sistem yang digunakan ada metode pengembangan prototipe. Hasil dari penelitian ini adalah sebuah sistem informasi yang dapat digunakan oleh Rumah Laundry Kiloan yang sudah di testing dengan pengujian black box testing.
\end{abstract}

Kata kunci: desktop, laundry, penjualan, prototipe, sistem informasi

\section{PENDAHULUAN}

Salah satu bisnis yang banyak orang-orang miliki adalah Laundry. Laundry adalah bisnis yang menggunakan jasa mencuci pakaian kotor. Dengan adanya laundry orang-orang yang lelah untuk mencuci pakaian nya di rumah dapat di bawa ke laundry dan menggunakan jasa laundry. Salah satu bisnis yang peneliti ingin meneliti adalah di Rumah Laundry Kiloan. Rumah Laundry Kiloan merupakan bisnis yang menawarkan jasa pencucian, dan penyetrikaan pakaian. Rumah Laundry Kiloan buka setiap hari kecuali hari libur nasional. Setiap hari hampir kurang lebih 20 pelanggan datang ke Rumah Laundry Kiloan untuk menggunakan jasa cuci pakaian.

Proses bisnis yang terjadi pada Rumah Laundry Kiloan dimulai dari pada saat pelanggan masuk dan memberikan kantong yang berisi pakaian pada pegawai Laundry, Pegawai langsung menanyakan paket apakah yang ingin digunakan. Terdapat 3 paket di laundry yaitu Jasa Laundry Regular, Express, atau setrika saja. Setelah pelanggan memberi tahu pilihan nya maka pegawai langsung menimbang pakaian tersebut di timbangan. Harga dimasukan sesuai dengan pilihan pelanggan. Timbangan akan otomatis menimbang berat nya pakaian tersebut dan menampilkan jumlah harga yang harus di bayar pelanggann. Pegawai akan mencatat total harga, jenis jasa laundry, dan berat nya pada nota. Untuk tanggal pengambilan pakaian ditentukan dengan paket jasa laundry yang dipilih pelanggan. Pelanggan memiliki 3 pilihan untuk membayar, pelanggan dapat membayar sepenuhnya langsung di hari itu juga, Membayar DP (Down Payment) pada hari itu juga dan pada saat 
pengambilan membayar sisanya, atau membayar full setelah pakaian sudah di bersihkan (membayar pada hari selesai nya pencucian yang sudah ditentukan). Nota tersebut berjumlah 2 dan 1 akan disimpan oleh pegawai laundry dan yang 1 lagi diberikan kepada pelanggan nya agar menjadi bukti transaksi yang akan digunakan untuk mengambil pakaian nya. Pencatatan transaksi yang dilakukan oleh pegawai dan pelanggan di catat di dalam nota. Nota tersebut merupakan kertas atau barang yang penting bagi pegawai laundry. Karena dengan adanya nota tersebut pegawai laundry memiliki barang bukti yang dapat digunakan untuk menyesuaikan dan mencatat pesanan pelanggan.

Pencatatan pendapatan perharian juga masih ditulis di dalam Buku. Di dalam buku tersebut berisi data-data pelanggan yang masuk dan yang keluar. Pelanggan yang masuk berarti pesanan-pesanan pelanggan yang ingin menggunakan jasa laundry pada hari itu. Pelanggan yang keluar berarti data-data pelanggan yang pakaian nya sudah di cuci dan diambil oleh pelanggan pada hari itu. Setelah pelanggan memberikan pakaian dan menerima nota di laundry, maka pelanggan dapat meninggalkan tempat laundry. pelanggan akan datang lagi pada hari yang sudah ditentukan untuk segera mengambil pakaian yang sudah di cuci.

Sistem yang saat ini masih digunakan masih memiliki kelemahan. Salah satu nya adalah pada pencatatan nota. Pegawai tidak menulis jumlah pakaian yang ada. Jadi pelanggan langsung memberikan kantong pakaian kotor nya dan pegawai langsung menimbang dan mencatat nya ke nota nya. Karena tidak mencatat jumlah pakaian nya atau pakaian apa saja yang dimiliki pelanggan maka ada kemungkinan besar terjadi resiko pakaian tersebut akan hilang dan kekurangan pada saat pelanggan mengambil pakaian tersebut. Adapun juga resiko yang dihadapi dengan mencatat menggunakan nota yaitu dengan adanya pencatatan masih menggunakan nota, resiko utama dari menggunakan metode tersebut adalah hilangnya atau kerusakan nya pada nota tersebut. Jika nota tersebut hilang maka akan menjadi masalah pada pencatatan dan penyimpanan bukti transaksi sehingga pegawai tidak dapat memasukan data-data pesanan atau transaksi pada buku.

Dengan menggunakan sistem pencatatan ini ada beberapa resiko yang dapat terjadi yaitu kerusakan pada buku. Jika kertas di buku robek atau basah kena air maka catatancatatan yang ada di buku bisa hilang dan bisa rusak. Dengan adanya masalah dan resiko-resiko tersebut, peneliti ingin membuat sebuah sistem berbasis desktop pada laundry agar dapat menanggulangi resiko-resiko yang ada dan membantu menyelesaikan masalah yang terjadi pada laundry tersebut.

Tujuan dari penelitian ini adalah merancang dan membangun sistem informasi penjualan laundry berbasis Desktop pada Rumah Laundry Kiloan yang dapat digunakan untuk megolah pencatatan data pelanggan dan laporan harian atau bulanan transaksi yang ada pada Rumah Laundry Kiloan.

\section{METODE PENELITIAN}

\section{A. Tahapan Penelitian}

Peneliti membuat tahapan penelitian dengan tujuan untuk menjelaskan aktivitas dan kegiatan yang dilakukan selama penelitian. Gambar Tahapan Penelitian dapat dlihat pada Gambar 1.

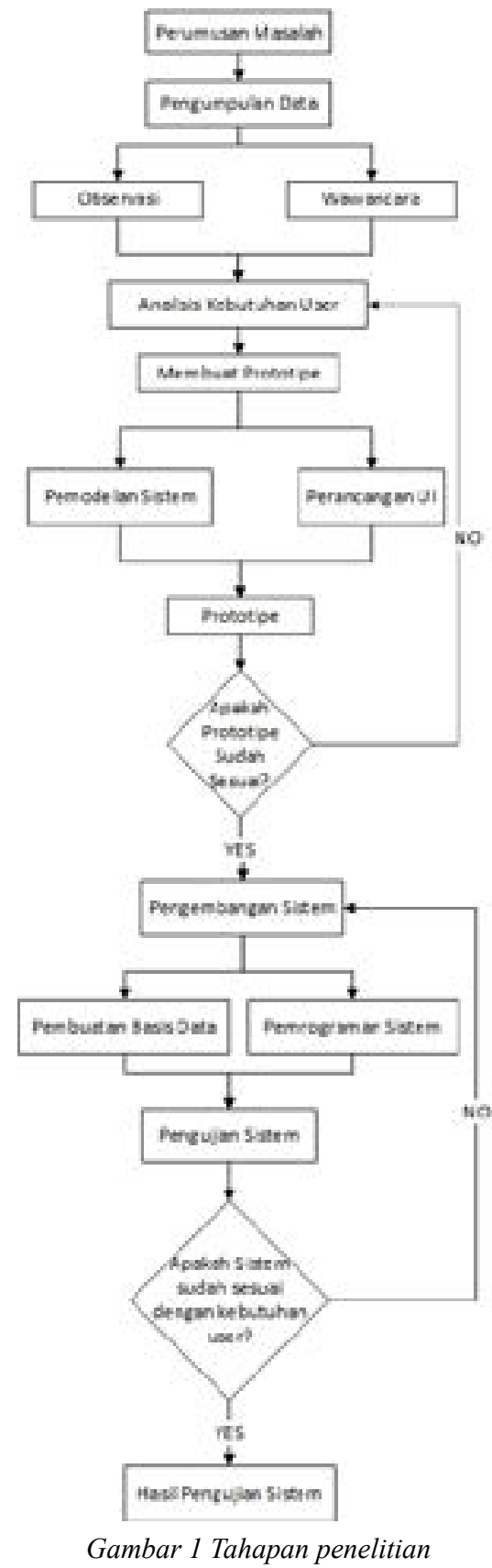




\section{B. Penelitian Terdahulu}

Penelitian terdahulu yang pertama adalah berjudul "Aplikasi Laundry Berbasis Java dan MySQL". Penelitian ini dilakukan oleh Erwin Hardianto, Purnomo Yulianto, Sultan Aulia A dari Politeknik NSC Surabaya. Tujuan dari penelitian nya adalah bagaimana membuat aplikasi laundry yang dapat mempermudah proses bisnis pada laundry tersebut. Platform dari aplikasi tersebut menggunakan Desktop. Bahasa pemrograman yang digunakan adalah Java. Aplikasi yang digunakan untuk membuat aplikasi tersebut adalah NetBeans IDE 8.1, Xampp. Database yang digunakan adalah MySQL. [1]

Penelitian terdahulu yang kedua adalah berjudul "Sistem Informasi Penjualan Pada Toko Hagas Tani Batu Malang". Penelitian ini dilakukan oleh Rahayu Widayanti, Bambang Ariebowo, Jauharul Maknunah dari jurusan Sistem Informasi STMIK Pradnya Pramita. Tujuan dari penelitian ini adalah Pemanfaatan sistem informasi penjualan berbasis desktop yang menghasilkan solusi untuk menangani masalahmasalah transaksi pembelian, penjualan, serta persediaan barang yang memungkinkan pengawasan barang secara aktual. Platform yang digunakan adalah Desktop. Bahasa Pemrograman dan aplikasi yang digunakan untuk membangun sistem adalah Visual Basic. Basis data yang digunakan adalah MySQL. [2]

Penelitian terdahulu yang ketiga adalah berjudul "Pembangunan Sistem Informasi Penjualan Obat Pada Apotek Punung". Penelitian ini dilakukan oleh Tri Utami, Bambang Eka Purnama dari Universitas Surakarta. Tujuan Penelitian ini adalah Menghasilkan Sistem Informasi berbasis dekstop pada Apotek Punung dan Mempermudah proses penjualan serta mengurangi kesalahan dalam pembuatan laporan penjualan pada Apotek Punung. Platform yang digunakan adalah Desktop. Bahasa pemrograman dan aplikasi pembuatan sistem yang digunakan adalah Java. Basis Data yang digunakan adalah MySQL. [3]

\section{Tinjauan Pustaka}

\section{Sistem}

Sistem adalah sekumpulan komponenkomponen yang bekerja, mencapai tujuan yang sama serta menghasilkan output yang sesuai dengan tujuan nya sistem tersebut [4].

Sistem memiliki ciri-ciri sebagai berikut [5]: 1) Sistem memiliki berbagai komponen didalamnya; 2) Setiap komponen pada sistem harus berhubungan; 3) Sistem memiliki Batasan; 4) Sistem memiliki tujuan (goals); 5) Sistem memiliki ruang lingkup; dan 6) Sistem memiliki 3 fase yaitu input, process, output.

\section{Informasi}

Informasi merupakan hasil pengolahan data yang dapat diterima dan memiliki manfaat dalam pengambilan keputusan kepada penerimanya. [6]

Ciri-ciri informasi yang berukalitas adalah [7]: 1) Relevan, Informasi yang didapatkan sesuai dengan kenyataan; 2) Handal, Informasi yang didapat dapat dipercaya; 3) Lengkap, Informasi yang didapat lengkap dan tidak kurang; 4) Tepat, Informasi yang diberikan tersedia tepat pada waktu nya saat dibutuhkan; 5) Dapat dipahami, Informasi yang diterima dapat dimengerti; 6) Dapat diverifikasi Informasi dapat dimengerti oleh kedua pihak; dan 7) Dapat diakses dengan mudah. Informasi yang dibutuhkan dapat didapatkan dengan pengguna dengan mudah.

\section{Sistem Infromasi Penjualan}

Sistem Informasi Penjualan adalah orang, alat, dan prosedur yang menghubungkan antara komputer dan manusia untuk menghasilkan sebuah informasi mengenai kegiatan penjualan [8].

\section{Prototyping}

Prototyping merupakan teknik pengembangan sistem yang menggunakan prototype untuk menggambarkan sistem, sehingga pengguna atau pemilik sistem mempunyai gambaran pengembangan sistem yang akan dilakukan. Teknik ini sering digunakan apabila pemilik sistem tidak terlalu menguasai sistem yang akan dikembangkannya sehingga dia memerlukan gambaran dari sistem yang akan dikembangkannya tersebut. Dengan Teknik prototyping, pengembang bisa membuat prototype terlebih dahulu sebelum mengembangkan sistem yang sebenarnya.

Requirements Prototype merupakan prototype yang dibuat oleh pengembang dengan mendifinisikan fungsi dan prosedur sistem dimana pengguna atau pemilik sistem tidak bisa mendefinisikan sistem tersebut. Tahapan langkah Requirements Prototype: 1) Analisis kebutuhan User, pengembang dan pengguna atau pemilik sistem melakukan diskusi dimana pengguna atau pemilik sistem menjelaskan kepada pengembang tentang kebutuhan sistem yang mereka inginkan; 2) Membuat prototype, pengembang membuat prototype dari sistem yang telah dijelaskan oleh pengguna atau pemilik system; 3) Menyesuaikan prototype dengan keinginan User, pengembang menanyakan kepada pengguna atau pemilik sistem tentang prototype yang sudah dibuat, apakah sesuai atau tidak dengan kebutuhan system; 
4) Membuat sistem baru, pengembang menggunakan prototype yang sudah dibuat untuk membuat sistem baru; 5) Melakukan testing sistem, pengguna atau pemilik sistem melakukan uji coba terhadap sistem yang dikembangkan; 6) Menyesuaikan dengan keinginan User, sistem disesuaikan dengan keinginan User dan kebutuhan sistem, jika sudah sesuai sistem siap digunakan; dan 7) Menggunakan Sistem [9].

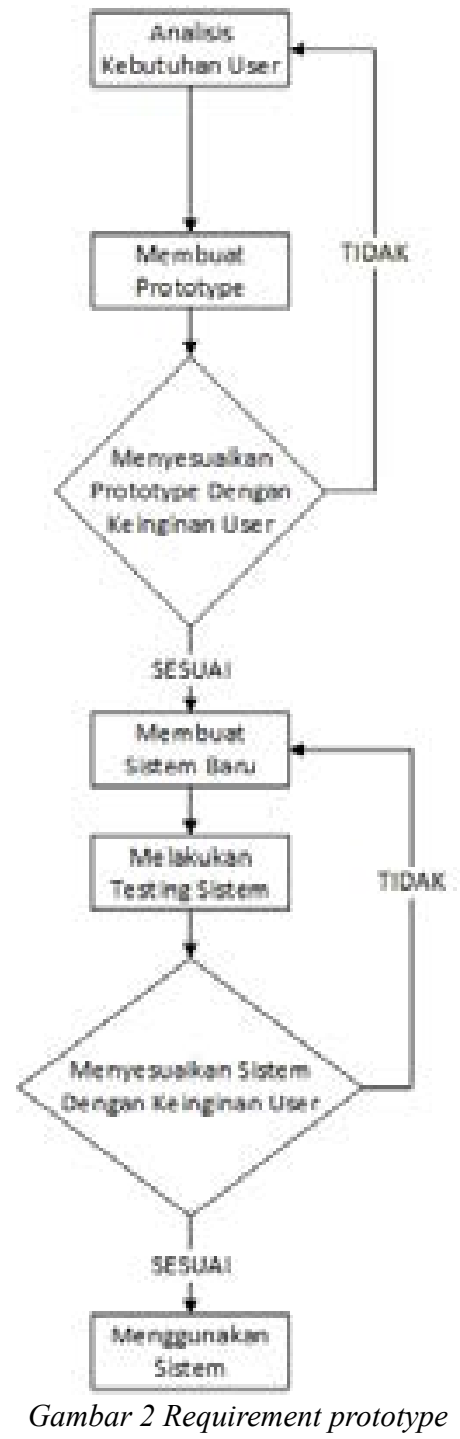

\section{Black Box Testing}

Black Box Testing adalah testing yang dilakukan penguji dengan hanya melakukan pengujian pada proses bagian luarnya. Test ini hanya memandang perangkat lunak dari sisi spesifikasi dan kebutuhan yang di bagian awal perancangan sistem [10].

Black Box Testing memiliki beberapa pengujian dengan cara dan tujuan yang berbeda. Salah satu nya adalah Pengujian Alfa (Alpha Testing). Alpha Testing adalah pengujian dimana pengguna (User) diminta untuk menggunakan aplikasi dan peneliti (pembuat aplikasi) akan mencatat setiap masukan atau tindakan yang dilakukan oleh User [11].

\section{HASIL DAN PEMBAHASAN}

\section{A. Analisis Sistem Berjalan}

Berdasarkan hasil pengumpulan data yang telah dilakukan peneliti sebelumnya, peneliti akan membuat cross functional flowchart sebagai alat untuk menggambarkan proses dan menjelaskan proses bisnis pada Rumah Laundry Kiloan. Proses bisnis tersebut dijelaskan menjadi 2 bagian yaitu pada saat pelanggan datang dan memberikan pakaian dan pada saat pelanggan ingin mengambil pakaian setelah selesai di cuci. Analisis sistem berjalan tersebut dapat dilihat pada Gambar 3, 4 dan 5 .
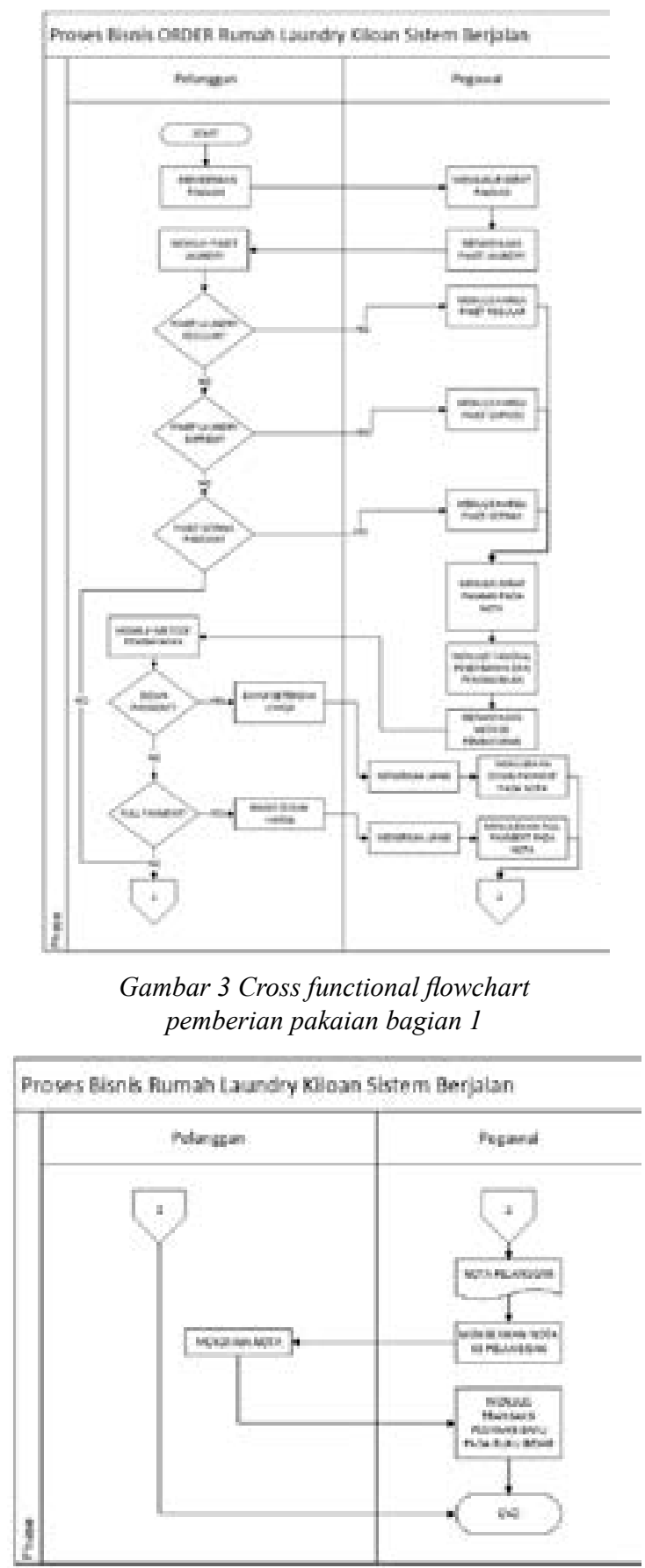

Gambar 4 Cross functional flowchart pemberian pakaian bagian 2 


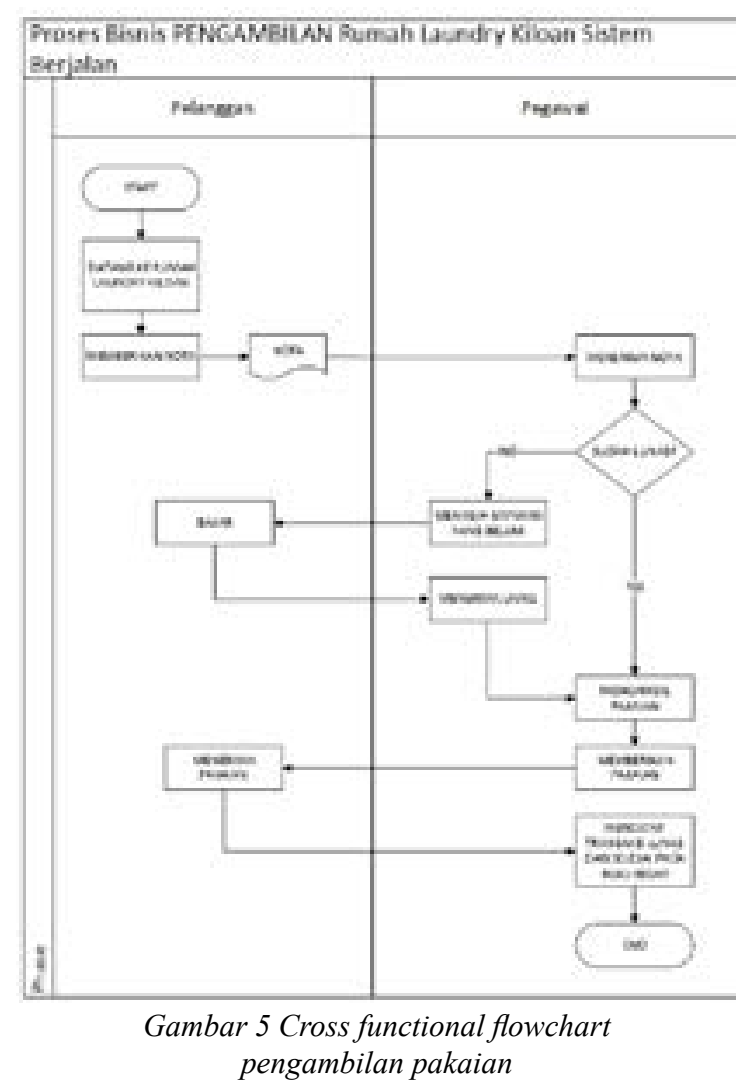

Berdasarkan sistem yang sedang berjalan saati ini, memiliki masalah-masalah sebagai berikut: 1) Pencatatan transaksi masih enggunakan buku dan masih menggunakan sistem konvensional; 2) Penyimpanan bukti Nota pada tempat kerja bertumpuk sehingga terdapat tinggi nya resiko kehilangan dan kerusakan pada nota tersebut; dan 3) Penghitungan penghasilan masih menggunakan kalkulator sehingga hasil tersebut dapat memperlambat proses bisnis dan memiliki resiko kesalahan pada saat menghitung penghasilan.

\section{B. Pemodelan Sistem}

Dalam pemodelan sistem, peneliti melakukan rancangan sistem yang menggunakan unifield model language (UML) untuk menjelaskan hal hal mengenai perancangan sistem yang akan dibuat seperti use case diagram, class, diagram, activity diagram.

\section{Use Case Diagram}

Use Case Diagram adalah diagram yang digunakan peneliti untuk menjelaskan siapa saja dan apa saja proses pada sistem usulan tersebut. Peneliti membuat use case diagram sesuai dengan aktor atau orang yang akan menggunakan sistem tersebut. Peneliti juga menggambarkan aktivitas apa saja yang dapat dilakukan dari setiap aktor tersebut. Gambar Use Case Diagram ditunjukkan pada Gambar 6.

\section{Activity Diagram}

Activity Diagram adalah diagram yang digunakan untuk menjelaskan aktivitas-aktivitas yang dilakukan oleh User di dalam sistem. Activity Diagram juga menjelaskan aktivitas yang ada di dalam use case.

\section{Class Diagram}

Class diagram adalah diagram yang menggambarkan atau menjelaskan struktur dan atribut sistem. Class Diagram memiliki kelas-kelas yang memiliki suatu atribut dan operasi dalam sistem. Gambar Class Diagram Sistem Informasi Penjualan Rumah Laundry Kiloan ditunjukkan pada Gambar 7.

\section{Perancangan Antarmuka}

Tahap ini merupakan perancangan antarmuka aplikasi Sistem Informasi Penjualan PD Gading Mulia. Perancangan antarmuka aplikasi ditunjukkan sebagai berikut.

\section{Rancangan Antarmuka Login}

Perancangan Tampilan Login memiliki kolom Username dan Password yang digunakan untuk memasukkan Username dan Password pengguna. Tombol Login dan bersihkan. Tombol Login berfungsi untuk masuk ke dalam sistem jika sudah mengisi Username dan Password dan tombol bersihkan untuk mengosongkan kolom Username dan Password. Tombol Keluar digunakan untuk keluar dari sistem dan menutup aplikasi. Perancangan Tampilan Login ditunjukkan pada Gambar 8.

\section{Rancangan Antarmuka Pegawai}

Pada perancangan tampilan pegawai, pegawai memiliki 2 fitur yaitu transaksi dan pelanggan. Transaksi memberi hak ke pegawai untuk mengurus transaksi harian yang datang di rumah laundry kiloan dan pelanggan digunakan untuk mencatat pelanggan pada rumah laundry kiloan. Terdapat 3 tombol yaitu tombol pegawai, tombol transaksi, dan tombol logout. Tombol transaksi digunakan untuk menampilkan halaman transaksi. Tombol pelanggan digunakan untuk menampilkan tampilan pegawai. Tombol logout digunakan untuk kembali ke halaman login. Perancangan Tampilan Beranda Pegawai ditunjukkan pada Gambar 9.

\section{Rancangan Antarmuka Admin}

Pada perancangan tampilan admin, admin memiliki fitur untuk melihat pengguna, pakaian, laporan, dan paket jasa. Di halaman admin terdapat 5 


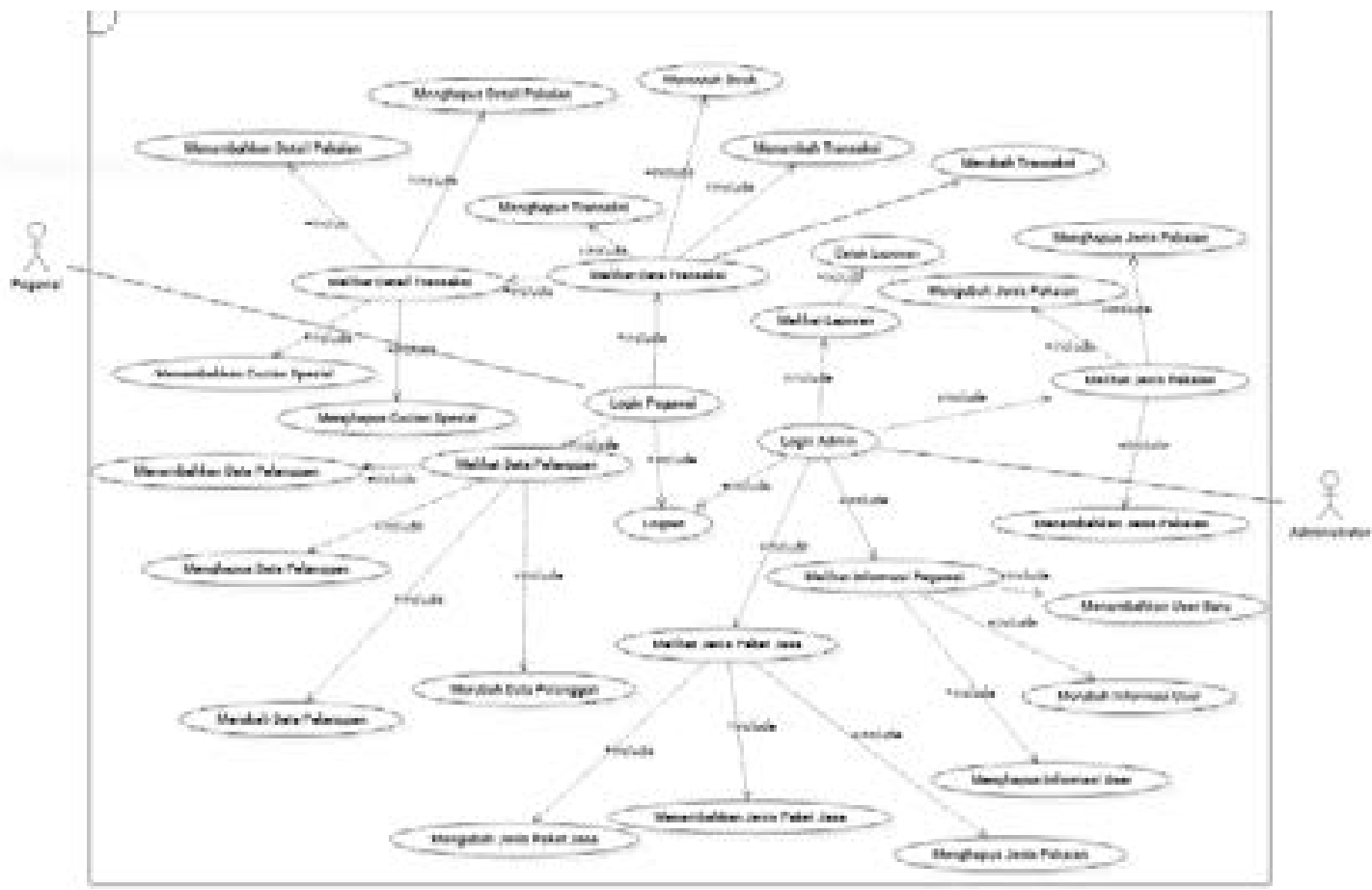

Gambar 6 Rancangan use case

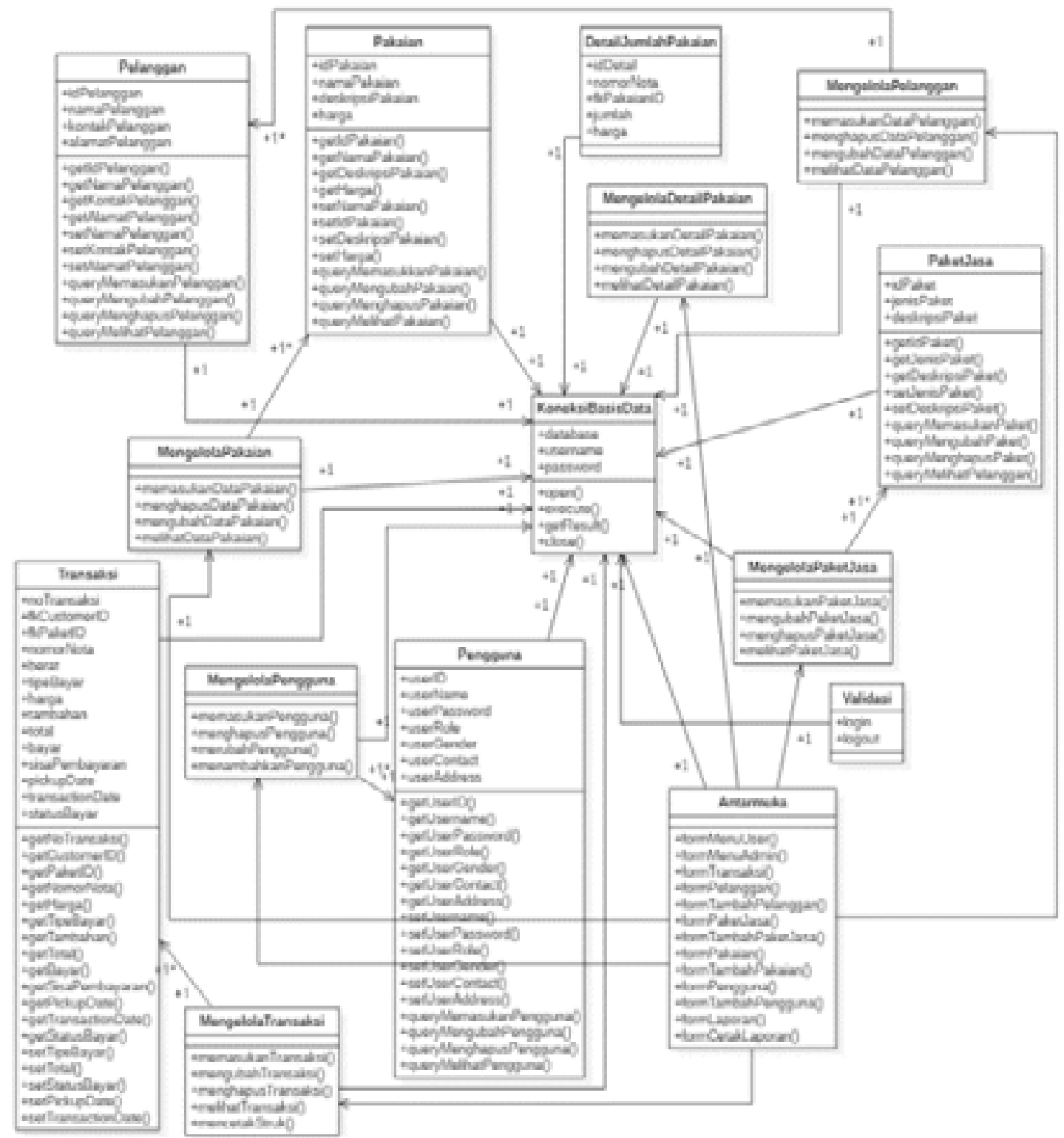

Gambar 7 Class diagram PD gading mulia 


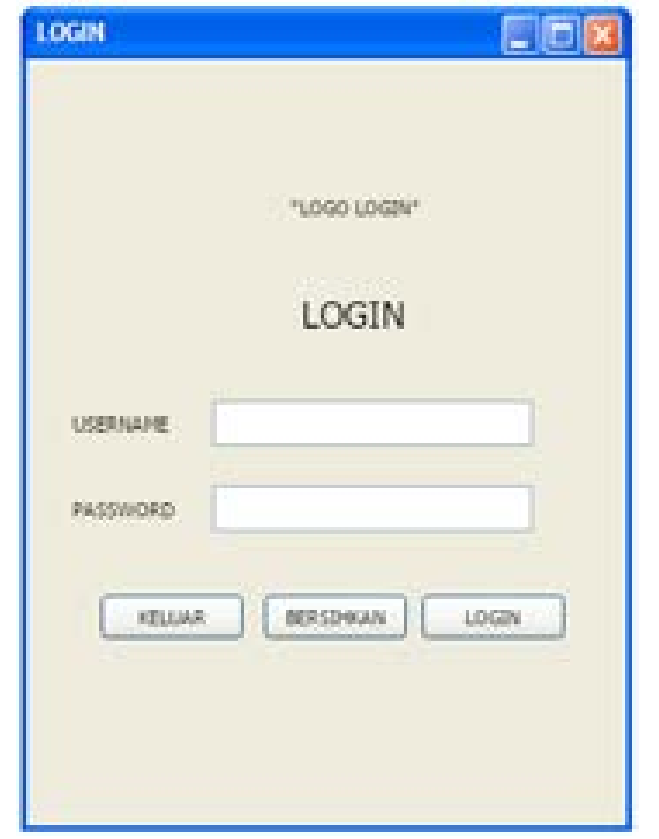

Gambar 8 Rancangan antarmuka login

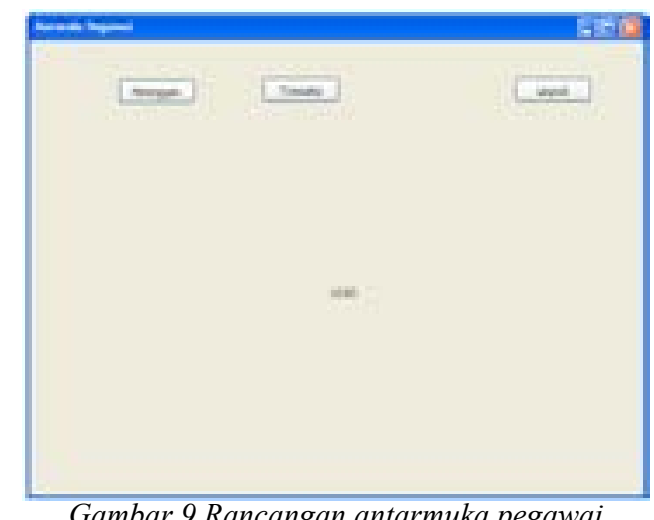

Gambar 9 Rancangan antarmuka pegawai

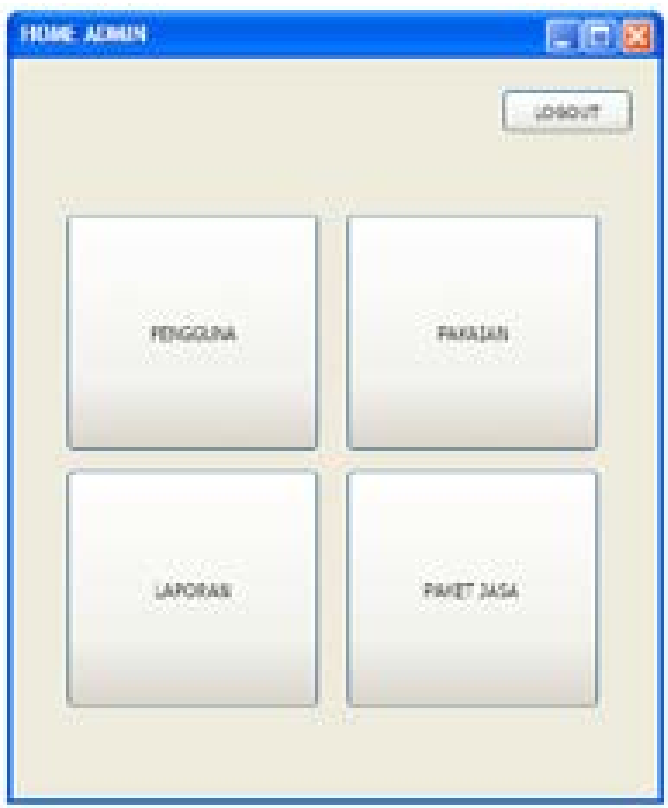

Gambar 10 Rancangan antarmuka admin

tombol yaitu pengguna, pakaian, laporan, paket jasa, dan logout. Admin juga dapat melakukan manipulasi terhadap setiap informasi yang ada di pengguna, pakaian, laporan, paket jasa. Perancangan Tampilan Beranda Admin ditunjukkan pada Gambar 10.

\section{Rancangan Antarmuka Pelanggan}

Tampilan pengaturan pelanggan digunakan oleh pegawai untuk melihat, mengubah, dan menghapus data pelanggan yang ada. Tabel pelanggan akan menampilkan informasi pelanggan yang sudah terdaftar. Terdapat 3 kolom di sebelah kiri yaitu kolom nama pelanggan, kontak pelanggan, dan alamat pelanggan. Pada tampilan ini juga memiliki 3 tombol yaitu simpan perubahan untuk menyimpan perubahan, hapus untuk menghapus isi pada tabel dan basis data dan tambahkan untuk menambahkan pelanggan. Gambar Perancangan Tampilan Pengaturan Pelanggan ditunjukkan pada Gambar 11.

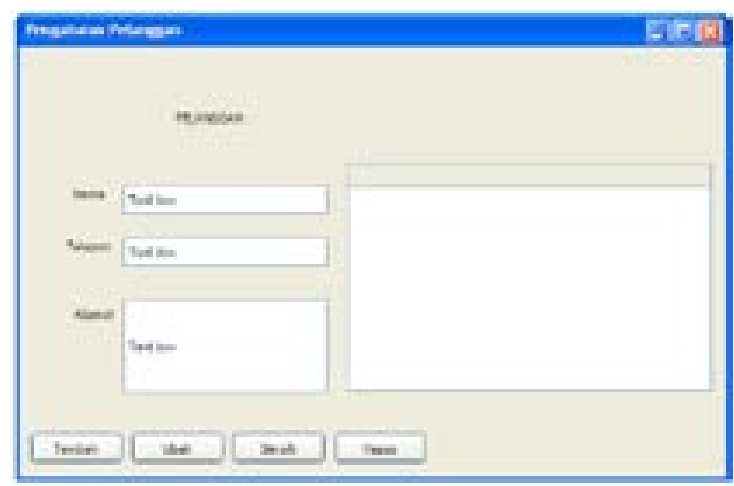

Gambar 11 Rancangan antarmuka pelanggan

\section{Rancangan Antarmuka Transaksi}

Perancangan tampilan transaksi digunakan untuk menampilkan transaksi yang sudah ditambahkan pada sistem dan basis data. Di tampilan ini pegawai dapat melihat, menghapus, dan mengubah informasi transaksi yang sudah dilakukan. Jika pengguna ingin melakukan perubahan pada data transaksi maka pengguna dapat menekan pada baris transaksi pada tabel dan tampilan untuk edit dan hapus akan muncul. Gambar Perancangan Tampilan Transaksi ditunjukkan pada Gambar 12.

\section{Rancangan Antarmuka Pengguna}

Tampilan pegaturan pengguna digunakan untuk mengakses data-data pengguna yang sudah

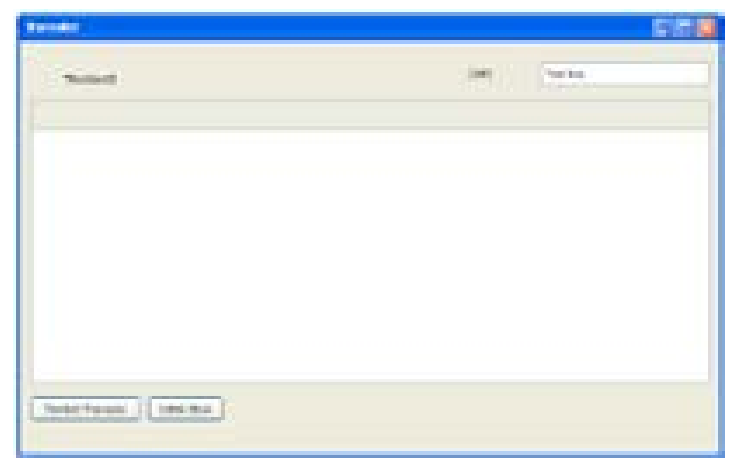

Gambar 12 Rancangan antarmuka transaksi 
terdaftar pada sistem dan basis data. Di tampilan ini, admin dapat melihat, merubah, dan menghapus pengguna yang ada. Tampilan ini memiliki kolom ID, username, kata sandi, kontak, dan alamat serta 4 radio button yaitu untuk memilih jabatan dan jenis kelamin. Tabel yang ada di sebelah kanan pada tampilan akan menampilkan nama-nama pengguna yang sudah pernah terdaftar di sistem dan basis data Rumah Laundry Kiloan. Pengguna dapat mengganti informasi yang berada di dalam tabel dengan menekan baris yang ada di dalam tabel dan memilih pengguna yang ingin diganti. Gambar Perancangan Tampilan Pengaturan Pengguna ditunjukkan pada Gambar 13

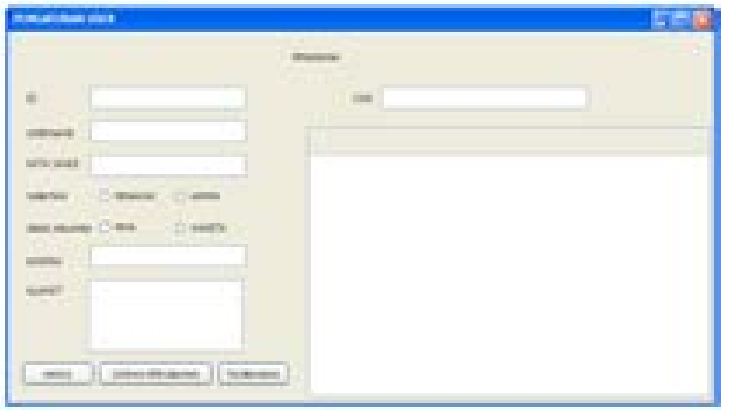

Gambar 13 Rancangan antarmuka pengguna

\section{Rancangan Antarmuka Paket Jasa}

Perancangan tampilan pengaturan paket jasa ini digunakan untuk melihat, menghapus, dan merubah paket jasa yang ada. Fitur ini hanya dapat digunakan oleh admin. Disebelah kanan ada tabel yang menampilkan informasi mengenai paket jasa apa saja yang ada di basis data. Pada tampilan ini memiliki 3 tombol yaitu simpang perubahan, hapus, dan tambahkan. Simpan perubahan digunakan untuk menyimpan perubahan yang telah diubah pada kolom isiian di atas nya. Tombol hapus digunakan untuk menghapus baris yang ada pada tabel setelah dipilih. Tombol tambahkan akan menampilkan halaman tambahkan paket jasa dimana Admin dapat mengisi dan menambahkan jenis paket jasa. Perancangan Tampilan Pengaturan Paket Jasa ditunjukkan pada Gambar 14.

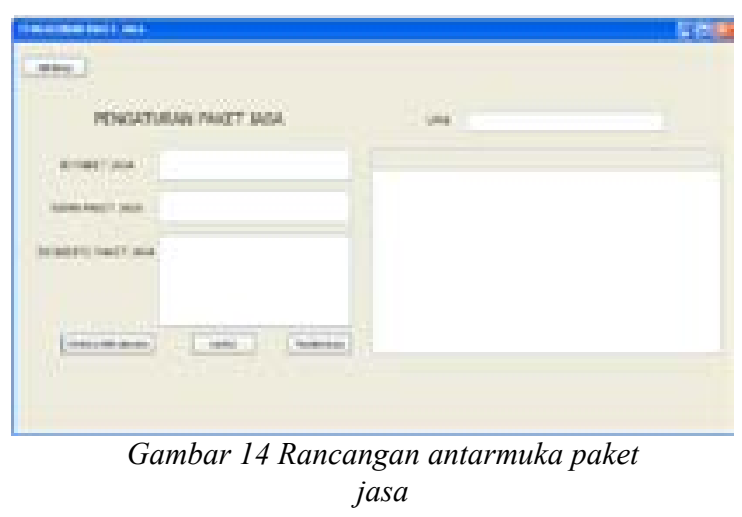

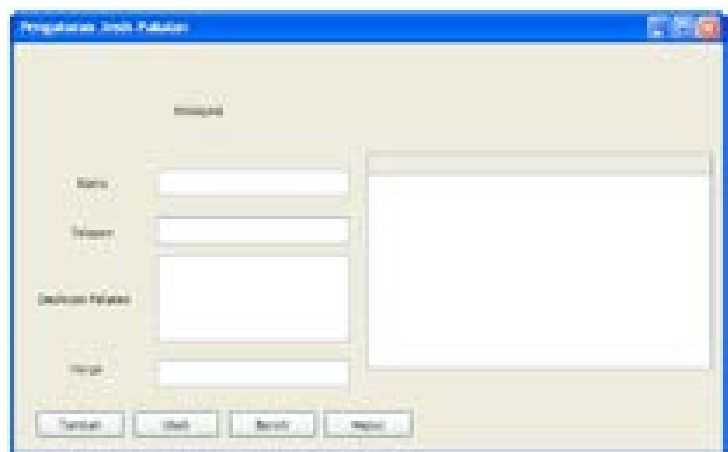

Gambar 15 Jenis Pakaian

\section{Rancangan Antar Muka Pakaian}

Pada perancangan tampilan pengaturan pakaian, hanya pegawai yang memiliki akses untuk melihat tampilan ini. Fitur ini digunakan oleh pegawai untuk mengubah dan menghapus jenis pakaian yang ada. Pada tampilan ini, pengguna juga dapat melihat jenis pakaian apa saja yang sudah ada di dalam tabel. Perancangan Tampilan Pengaturan Jenis Pakaian ditunjukkan pada Gambar 15.

\section{Rancangan Antar Muka Laporan}

Perancangan Tampilan Laporan ini digunakan untuk melihat dan mencetak laporan. Tampilan ini hanya dapat diakses oleh Admin. Gambar Perancangan Tampilan Laporan ditunjukkan pada Gambar 16.

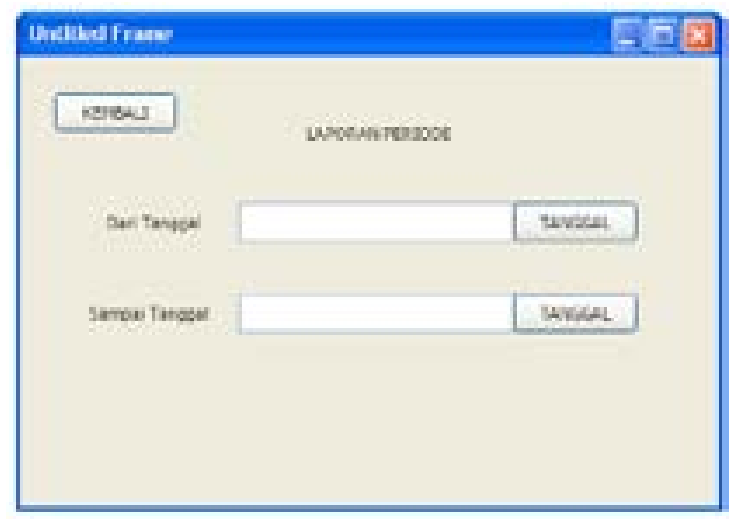

Gambar 16 Rancangan antarmuka laporan

\section{Pembuatan Basis Data}

Berikut ini merupakan pembuatan basis data yang dibagi menjadi dua, yaitu PDM (Physical Data Model). PDM menjelaskan model basis data yang menggunakan beberapa tabel untuk menggambarkan data dan relasi data tersebut.

\section{E. Implementasi Sistem}

Implementasi sistem merupakan hasil atau output dari sistem yang sudah dibangun. Dalam hal ini adalah aplikasi Sistem Informasi Penjualan pada Rumah Laundry Kiloan. Implementasi ini berisikan 
tentang screen shot atau capture dari tampilan sistem yang sudah dibangun oleh peneliti.

\section{Tampilan Halaman Login}

Tampilan Login terdapat kolom Username dan Password. Form ini juga memiliki 3 tombol yang memiliki fungsi yang berbeda. Tombol Keluar berfungsi untuk keluar dari aplikasi dan menutup aplikasi. Tampilan Login dapat ditunjukkan pada Gambar 17.

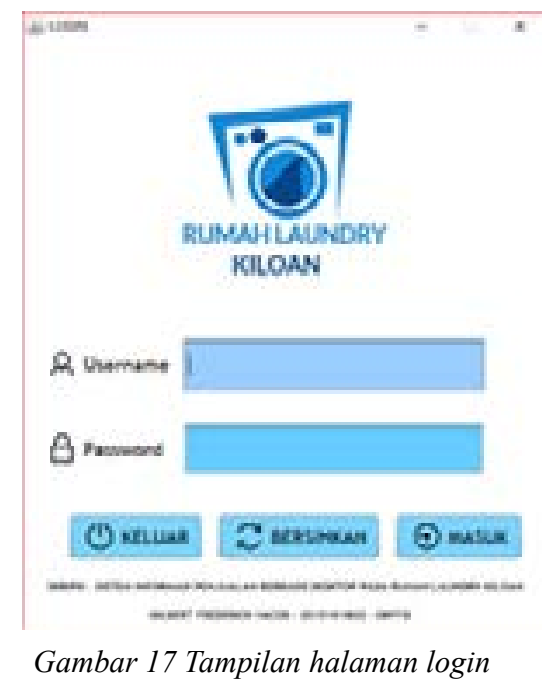

\section{Tampilan Halaman Pegawai}

Tampilan ini hanya dapat diakses oleh Pegawai. Tampilan ini beriisi 3 tombol yang menuju ke form yang berbeda. Tombol pelanggan akan menuju ke bagian pelanggan dimana User dapat melakukan aktivitas menambah, mengapus dan merubah data pelanggan. Tampilan Halaman Pegawai ditunjukkan pada Gambar 18.

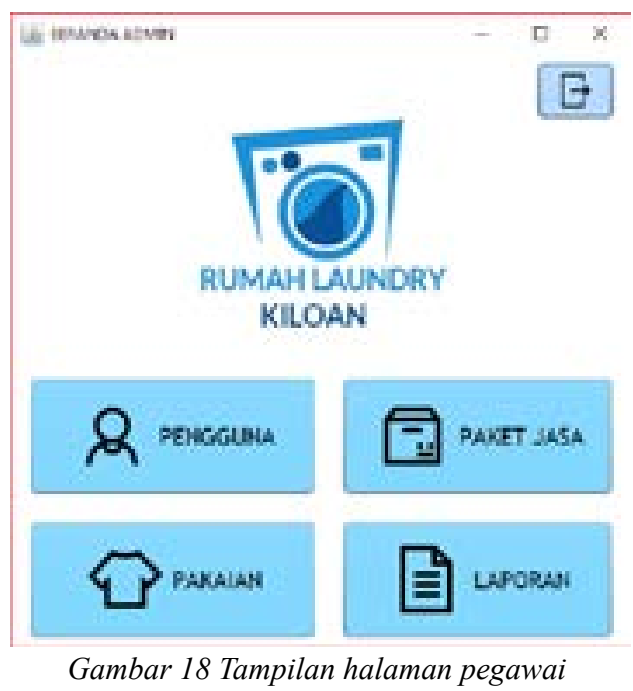

\section{Tampilan Halaman Admin}

Tampilan Halaman Admin ini hanya dapat diakses oleh pengguna yang memiliki jabatan sebagai
Admin. Admin disini juga bisa berupa pemilik Rumah Laundry Kiloan atau orang yang dipercayai pemilik untuk menjalankan bisnis Rumah Laundry Kiloan. Halaman admin ini memiliki 4 tombol yaitu Pengguna, Paket Jasa, Pakaian, dan Laporan. seperti pada Gambar 19.

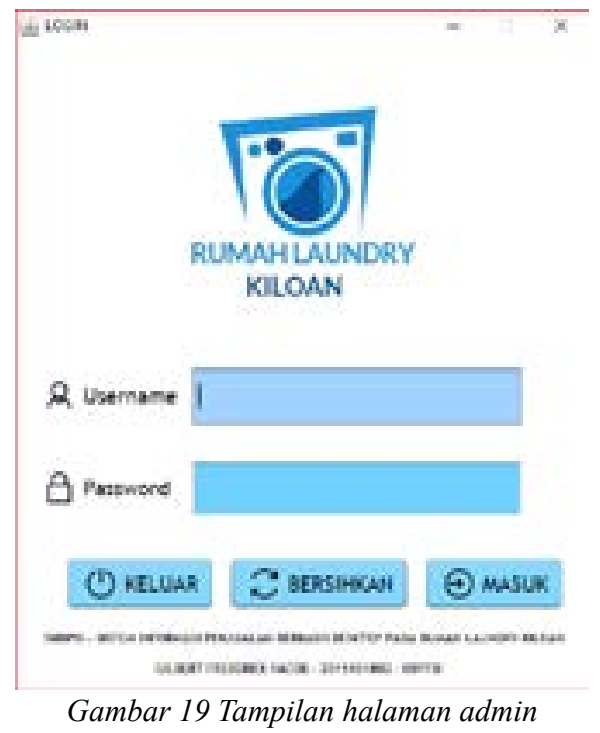

\section{Tampilan Halaman Transaksi}

Tampilan halaman transaksi ini digunakan untuk melihat, mengubah, dan menghapus informasi transaksi. Pada halaman ini terdapat tabel yang berisi informasi transaksi-transaksi yang ada pada Rumah Laundry Kiloan. Tampilan halaman transaksi di tunjukkan pada Gambar 20.

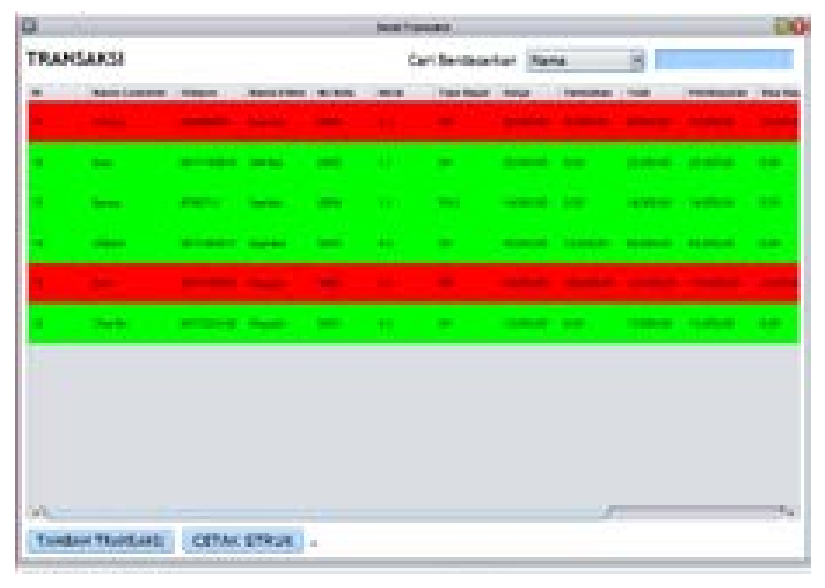

Gambar 20 Tampilan halaman transaksi

\section{Tampilan Halaman Pelanggan}

Tampilan halaman pelanggan adalah halaman dimana pengguna dapat mengubah dan menghapus data pelanggan. Tampilan halaman pelanggan ditunjukkan pada Gambar 21.

\section{Tampilan Halaman Paket Jasa}

Tampilan halaman Paket Jasa adalah halaman dimana admin dapat mengubah dan menghapus jenis 


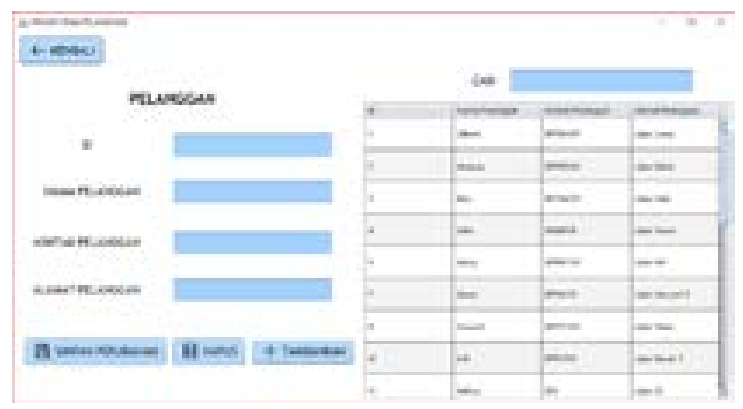

Gambar 21 Tampilan halaman pelanggan

paket jasa yang ada. Tampilan Halaman Paket Jasa ditunjukkan pada Gambar 22.

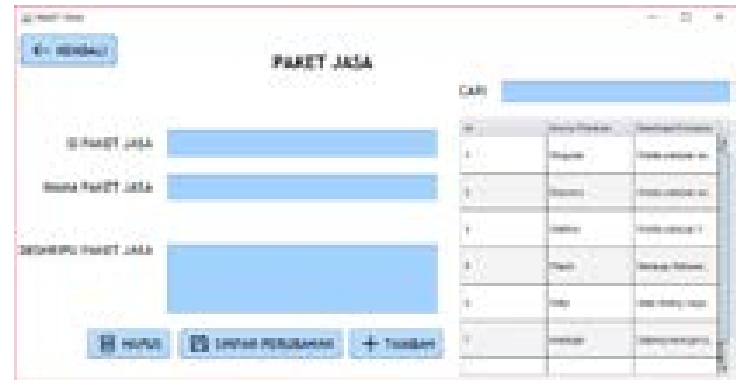

Gambar 22 Tampilan halaman paket jasa

\section{Tampilan Halaman Pakaian}

Tampilan Halaman Jenis Pakaian berfungsi untuk menampilkan, mengubah, dan menghapus jenis pakaian yang ada pada basis data. Di sebelah kanan terdapat tabel yang berisi ID Pakaian, Nama Pakaian, Deskripsi Pakaian dan Harga. Tampilan Halaman Pakaian ditunjukkan pada Gambar 23.

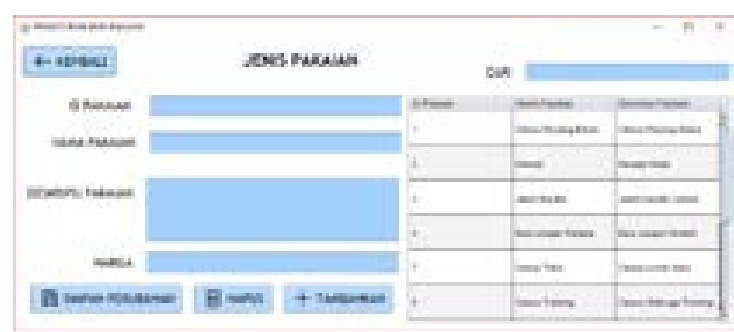

Gambar 23 Tampilan halaman jenis pakaian

\section{Tampilan Halaman Laporan}

Tampilan Halaman Laporan ini berfungsi untuk menampilkan tabel transaksi dan mencetak tabel transaksi tersebut menjadi laporan. Tampilan Halaman Laporan ditunjukkan pada Gambar 24.

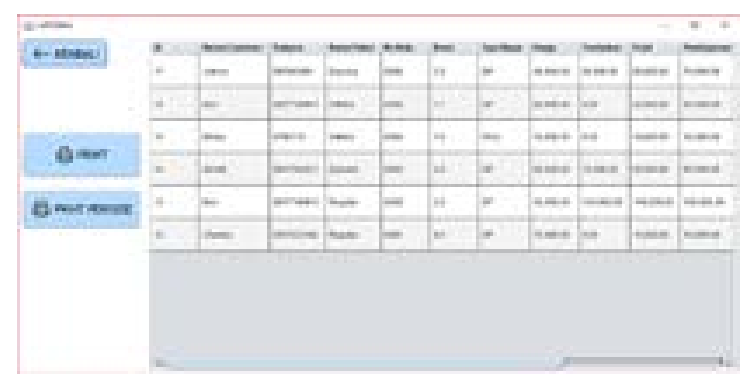

Gambar 25 Tampilan halaman laporan
Tabel 1 Skenario pengujian

\begin{tabular}{|c|c|}
\hline 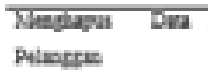 & 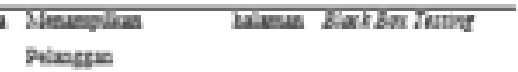 \\
\hline Therring & 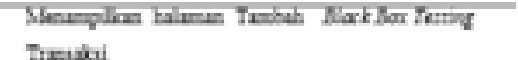 \\
\hline Tamase & Tixaseli \\
\hline 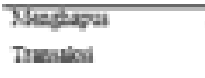 & 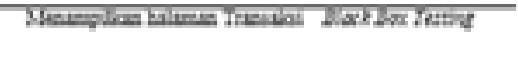 \\
\hline $\begin{array}{l}\text { Theante Ditel } \\
\text { Devaie }\end{array}$ & 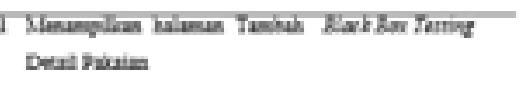 \\
\hline 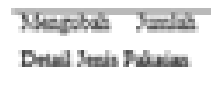 & 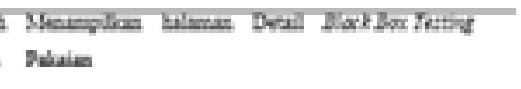 \\
\hline 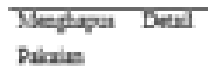 & 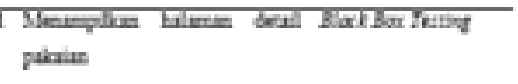 \\
\hline Meacinivintex & 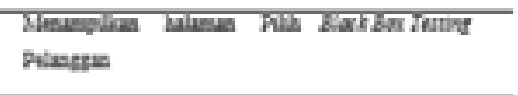 \\
\hline 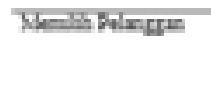 & 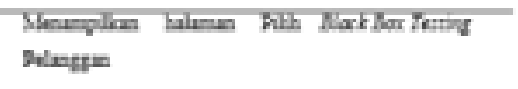 \\
\hline Thenter Vum & 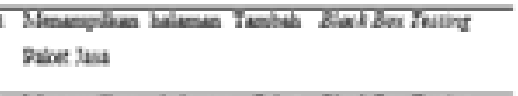 \\
\hline $\begin{array}{l}\text { Therphis Fine } \\
\text { lane }\end{array}$ & 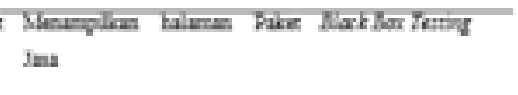 \\
\hline 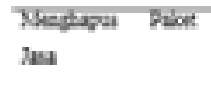 & 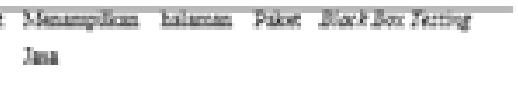 \\
\hline 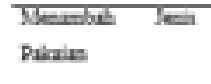 & 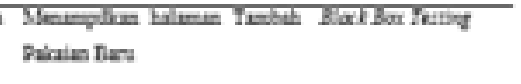 \\
\hline Keim Cy & Tensh Kangiven \\
\hline Lesos Presous & 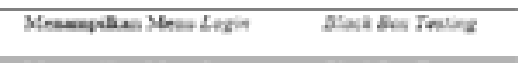 \\
\hline EeponAdmin & Mramepilan Whes Laria \\
\hline Lowate Pearina & 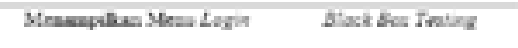 \\
\hline Logow Astain & 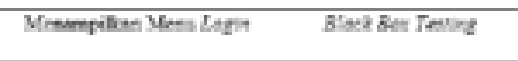 \\
\hline 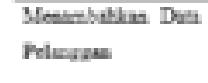 & 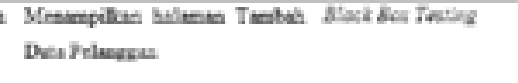 \\
\hline 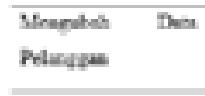 & 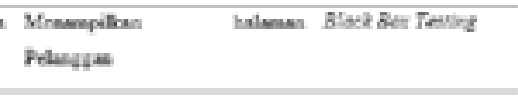 \\
\hline engubuh Jeris: & 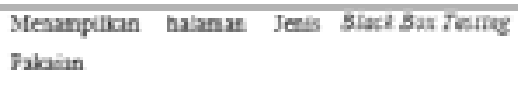 \\
\hline $\begin{array}{l}\text { Mengeapus Jeris: } \\
\text { Pakain }\end{array}$ & 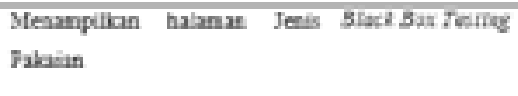 \\
\hline $\begin{array}{l}\text { Menisital } \\
\text { Peegrus }\end{array}$ & 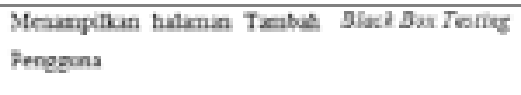 \\
\hline Merpibus Pergfuad & 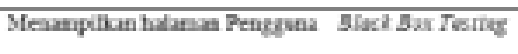 \\
\hline $\begin{array}{l}\text { Menthous } \\
\text { Peagrue }\end{array}$ & 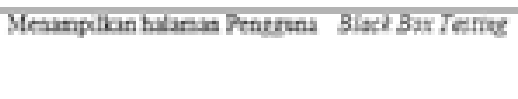 \\
\hline Melifat L zpocan & 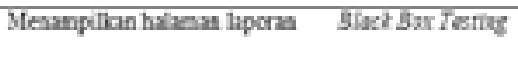 \\
\hline$t$ & Mesimpillan halinis liperia \\
\hline
\end{tabular}

\section{H. Pengujian Sistem}

Pada tahap ini peneliti menggunakan black box testing sebagai metode untuk melakukan pengujian sistem. Klasifikasi yang digunakan dalam Black Box Testing ini adalah Alpha Testing. Pengujian ini dilakukan langsung bersama dengan pegawai Rumah Laundry Kiloan. 


\section{Skenario Pengujian}

Pada skenario pengujian, pegawai akan melihat secara langsung selama pengujian aplikasi berlangsung. Pegawai memiliki peran penting dalam skenario pengujian, karena pegawai yang akan menyesuaikan apakah sistem yang dibangun peneliti cocok dengan kebutuhan awal. Skenario Pengujian ditujukkan pada Tabel 1.

\section{Hasil Pengujian}

Pengujian yang digunakan peneliti adalah black box testing dan klasifikasi alpha testing. Pengujian yang dilakukan adalah menguji fungsi dan fiturfitur yang ada di dalam sistem. Hasil dari pengujian yang dilakukan mendapatkan hasil sistem dapat berjalan dengan baik. Sehingga sistem tersebut dapat digunakan oleh Rumah Laundry Kiloan.

\section{SIMPULAN}

Sistem Informasi Penjualan Berbasis Desktop Pada Rumah Laundry Kiloan merupakan sistem informasi penjualan yang digunakan untuk menyimpan, menambahkan, dan manipulasi data-data yang terkait dengan transaksi. Metode pengembangan sistem yang digunakan adalah metode pengembangan Prototype (prototipe). Pemodelan sistem yang digunakan adalah Unified Modelling Language (UML). Software yang digunakan untuk membangun sistem ini adalah Netbeans 8.2. Bahasa pemrograman yang digunakan untuk membangun sistem ini adalah Bahasa Pemrograman Java. Jenis pengujian yang digunakan pada penelitian ini adalah pengujian sistem Black Box Testing dengan klasifikasi Alpha Testing. Dari hasil pengujian langsung bersama pegawai Rumah Laundry Kiloan, disimpulkan bahwa sistem yang dibangun sudah berjalan dengan baik.

\section{DAFTAR PUSTAKA}

[1] E. Hardianto, P. Yulianto and S. A. A, Aplikasi Laundry Berbasis Java dan MySQL, Surabaya: Politeknik NSC Surabaya, 2016.
[2] R. Widayanti, B. Ariebowo and J. Maknunah, "Sistem Informasi Penjualan Pada Toko Hagas Tani Batu Malang," SMATIKA Jurnal, vol. 8, no. 2, pp. 50-55, 2018.

[3] T. Utami and B. E. Purnama, "Pembangunan Sistem Informasi Penjualan Obat Pada Apotek Punung," Indonesian Journal on Networking and Security, vol. 4, no. 2, pp. 43-49, 2015.

[4] S. Mulyani, "Deskripsi Umum Sistem," in Metode Analisis dan Perancangan Sistem, Bandung, Abdi Sistematika, 2016, p. 2.

[5] S. Mulyani, "Ciri-ciri Sistem," in Metode Analisis dan Perancangan Sistem, Bandung, Abdi Sistematika, 2016, p. 4.

[6] A. Kadir, "Informasi," in Pengenalan Sistem Informasi Edisi Revisi, Yogyakarta, Penerbit ANDI Yogyakarta, 2014, p. 45.

[7] S. Sarosa, "Metodologi dan Pengembangan Sistem Informasi," in Metodologi Pengembangan Sistem Informasi, Jakarta, Indeks Jakarta, 2017, p. 2.

[8] D. W. Setiawati and Y. Rohayati, "Implementing Enterprise Resource Planning (ERP) In Sales Information System (SIS) of SME (Small Medium Enterprise) ABO Farm Indonesia," in 2014 International Conference on ICT For Smart Society (ICISS), Bandung, 2014.

[9] S. Mulyani, "Prototyping," in Metode Analisis dan Perancangan Sistem, Bandung, Abdi Sistematika, 2016, pp. 26-30.

[10] R. Wijayanto, "Perancangan Animasi Interaktif Pembelajaran Bahasa Inggris Untuk Kelas 2 Pada Mi Nurul Falah Ciater,” Evolusi, vol. 2, no. 1, p. 3, 2014.

[11] J. Simarmata, "Jenis-Jenis Pengujian," in Rekayasa Perangkat Lunak, Yogyakarta, ANDI, 2010, p. 321. 